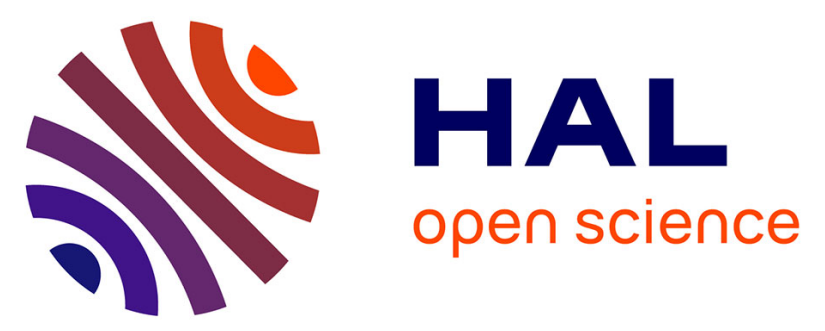

\title{
Prototypes of Lanthanide(III) Agents Responsive to Enzymatic Activities in Three Complementary Imaging Modalities: Visible/Near-Infrared Luminescence, PARACEST-, and T 1 -MRI
}

Jiefang He, Célia S. Bonnet, Svetlana V. Eliseeva, Sara Lacerda, Thomas

Chauvin, Pascal Retailleau, Frederic Szeremeta, Bernard Badet, Stéphane Petoud, Éva Tóth, et al.

\section{- To cite this version:}

Jiefang He, Célia S. Bonnet, Svetlana V. Eliseeva, Sara Lacerda, Thomas Chauvin, et al.. Prototypes of Lanthanide(III) Agents Responsive to Enzymatic Activities in Three Complementary Imaging Modalities: Visible/Near-Infrared Luminescence, PARACEST-, and T 1 -MRI. Journal of the American Chemical Society, 2016, 138 (9), pp.2913 - 2916. 10.1021/jacs.5b12084 . hal-01407004

\author{
HAL Id: hal-01407004 \\ https://hal.science/hal-01407004
}

Submitted on 14 Feb 2022

HAL is a multi-disciplinary open access archive for the deposit and dissemination of scientific research documents, whether they are published or not. The documents may come from teaching and research institutions in France or abroad, or from public or private research centers.
L'archive ouverte pluridisciplinaire HAL, est destinée au dépôt et à la diffusion de documents scientifiques de niveau recherche, publiés ou non, émanant des établissements d'enseignement et de recherche français ou étrangers, des laboratoires publics ou privés. 


\title{
Prototypes of Lanthanide(III) Agents Responsive to Enzymatic Activities in Three Complementary Imaging Modalities: Visible/Near-Infrared Luminescence, PARACEST- and $T_{1}$-MRI
}

\author{
Jiefang He, ${ }^{\mathrm{a}}$ Célia S. Bonnet, ${ }^{\mathrm{b}}$ Svetlana V. Eliseeva, ${ }^{\mathrm{b}}$ Sara Lacerda, ${ }^{\mathrm{b}}$ Thomas Chauvin, ${ }^{\mathrm{b}}$ Pascal \\ Retailleau, ${ }^{\mathrm{a}}$ Frederic Szeremeta, ${ }^{\mathrm{b}}$ Bernard Badet, ${ }^{\mathrm{a}}$ Stéphane Petoud, ${ }^{\mathrm{b}^{*}}$ Éva Tóth ${ }^{\mathrm{b}^{*}}$ and Philippe \\ Durand $^{\mathrm{a}^{*}}$ \\ ${ }^{a}$ Institut de Chimie des Substances Naturelles, CNRS UPR 2301, Université Paris-Saclay,1, av.de la Terrasse, 91198 \\ Gif-sur-Yvette, France;

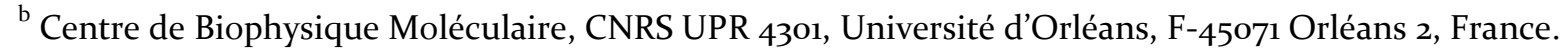 \\ KEYWORDS: responsive probe, near-infrared, lanthanide complex, luminescence, PARACEST, MRI, optical imaging.
}

\begin{abstract}
We report first prototypes of responsive lanthanide(III) complexes that can be monitored independently in three complementary imaging modalities. Through the appropriate choice of lanthanide(III) cations, the same reactive ligand can be used to form complexes providing detection either by $(i)$ visible $\left(\mathrm{Tb}^{3+}\right)$ and near-infrared $\left(\mathrm{Yb}^{3+}\right)$ luminescence, (ii) PARACEST- $\left(\mathrm{Tb}^{3+}, \mathrm{Yb}^{3+}\right)$ or (iii) $\mathrm{T}_{1}$-weighted $\left(\mathrm{Gd}^{3+}\right)$ MRI. The use of lanthanide(III) ions of different natures for these imaging modalities induces only a minor change in the structure of complexes that are therefore expected to have a single biodistribution and cytotoxicity.
\end{abstract}

Molecular imaging aims at visualizing biological objects or biochemical events at physiological, cellular and molecular levels within living cells, tissues or whole organisms for research, diagnostic or personalized medicine purposes. ${ }^{1}$ It relies on selective and/or responsive imaging agents optimized for a specific imaging modality, ${ }^{2}$ i.e. magnetic resonance imaging (MRI), ${ }^{3}$ optical imaging, ${ }^{4}$ ultrasonography, ${ }^{5}$ tomography ${ }^{6}$ etc. As each modality has its advantages and limitations, additional and less ambiguous information becomes accessible by sequentially or simultaneously combining several complementary techniques. ${ }^{7}$ The broad diversity of molecular events requires innovative solutions for their monitoring. Among them, enzymatic activities are of interest since their dysregulation is involved in many diseases. Smart imaging agents endowed with a responsive mechanism are required to detect these activities. ${ }^{8}$ Despite long-term efforts, progress in in vivo responsive imaging remains limited. ${ }^{9}$ An appealing strategy to accelerate the development of molecular imaging relies in the design of responsive probes suitable for different detection techniques using versatile molecular platforms, thus optimizing both time and efforts for synthetic work. Such platforms must combine a trigger, which can be adapted to a broad variety of molecular events, and a reporter moiety that can be detected by several imaging modalities. ${ }^{10}$ We previously designed a platform suitable for detection of enzymatic activities by PARACEST-MRI ${ }^{11}$ in which an enzymespecific trigger was coupled to a $\mathrm{Ln}^{3+}$-based reporter using a self-immolative spacer. We have demonstrated that the action of the selected enzyme resulted in elimination of the spacer associated with a change in MRI signal. In the present work, we set the basis of smart imaging probes which, in addition to PARACEST-MRI, allow the detection of enzymatic event by visible and near-infrared (NIR) luminescence and by T1-MRI. Bio-imaging in the NIR provides a major advantage of enhanced detection sensitivity due to the limited autofluorescence of biological tissues in this energy window. ${ }^{12}$ Several NIRemitting $\mathrm{Ln}^{3+}$ ions ${ }^{13}$ proved attractive for microscopy imaging of living cells. ${ }^{14}$ Moreover, $\mathrm{Ln}^{3+}$-based imaging agents possess several complementary advantages over organic fluorophores, such as sharp emission bands (for spectral discrimination) and strong resistance to photobleaching. ${ }^{15}$

As $\mathrm{Ln}^{3+}$ cations possess versatile magnetic and optical properties while having similar reactivities, ${ }^{16}$ we have designed a molecular platform that can be made responsive and that is compatible with the complementary imaging modalities previously described (Scheme 1). Ligand $\mathbf{H}_{3} \mathbf{L}_{\mathbf{1}}$ is a $\mathrm{DO}_{3} \mathrm{~A}$ derivative substituted by a pyridylmethyl moiety. The pyridine has multiple roles here: (i) to provide a donor atom for stable $\mathrm{Ln}^{3+}$ complexation, ${ }^{17}$ (ii) to act as a sensitizer for $\mathrm{Ln}^{3+}$ luminescence (antenna effect), ${ }^{18}$ and (iii) to introduce additional functionalities, in particular a self-immolative benzyl carbamate which will make this reporter responsive to molecular events such as enzymatic cleavage, as previously reported. ${ }^{11}$ The enzymatic cleavage of such probe and the elimination of the self-immolative arm will induce the transformation of the carbamate into 
an amine ${ }^{19}$ with subsequent changes in the coordination environment of the $\mathrm{Ln}^{3+}$ ion and modification of its hydration state. We hypothesized that such switching would be detectable by both visible and NIR luminescence as well as by $\mathrm{T}_{1^{-}}$and PARACEST-MRI depending on the nature of the $\mathrm{Ln}^{3+}$. We note that PARACEST and $\mathrm{T} 1$ agents cannot be used simultaneously since the $\mathrm{T}_{1}$ agent destroys the CEST signal, however, sequential imaging of the same animal in the two techniques can ascertain the findings and provide more accurate information. On the other hand, the luminescence capability provides higher sensitivity and resolution at the cellular level giving complementary information. $\mathbf{L} \mathbf{L}_{\mathbf{1}}$ are synthetically accessible model complexes of the responsive probes that will bear the self-immolative benzyl carbamate linker and an enzyme-specific substrate (R). For instance, $\beta$-D galactopyranoside can be used as a substrate for the detection of $\beta$-galactosidase. $\mathbf{L n L}_{2}$ complexes are the end product of the enzymatic cleavage of $\mathbf{L n L}_{\mathbf{1}}$.

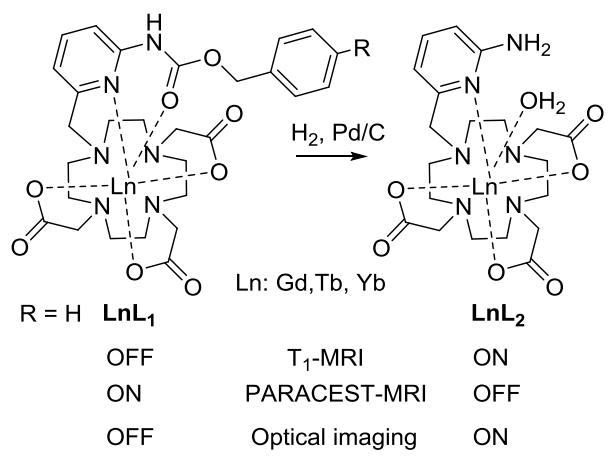

Scheme 1. $\operatorname{Ln}^{3^{+}}$complexes as prototypes of enzyme responsive probes for detection by visible $\left(\mathrm{Tb}^{3+}\right)$ or nearinfrared $\left(\mathrm{Yb}^{3+}\right)$ luminescence, by $\mathrm{T}_{1}$-weighted- $\left(\mathrm{Gd}^{3+}\right)$ or by PARACEST- $\left(\mathrm{Yb}^{3^{+}}, \mathrm{Tb}^{3^{+}}\right)$MRI. The $\mathrm{R}$ in $\mathbf{L n L}_{\mathbf{1}}$ can be replaced by an appropriate substrate to afford enzyme sensitivity and specificity.

In order to test this concept, we synthesized and investigated $\mathrm{Gd}^{3+}, \mathrm{Yb}^{3+}$ and $\mathrm{Tb}^{3+}$ complexes of $\mathbf{H}_{3} \mathbf{L}_{1}$ and $\mathbf{H}_{3} \mathbf{L}_{2}$ (Scheme 1, Supporting Information). Synthesis of $\mathbf{H}_{3} \mathbf{L}_{1}$ was achieved in eight steps with a $13 \%$ overall yield starting from commercially available 2-bromo-6-amino pyridine. $\mathbf{L n L}_{\mathbf{1}}$ complexes were formed at room temperature in a $\mathrm{pH}$-controlled aqueous solution upon addition of the corresponding $\mathrm{LnCl}_{3}$ to the ligand. Their hydrogenolysis over palladium-charcoal in water led to the formation of the corresponding $\mathbf{L} \mathbf{n L}_{2}$ chelates.

Absorption spectra of the ligands $\mathbf{H}_{3} \mathbf{L}_{\mathbf{1}}$ and $\mathbf{H}_{3} \mathbf{L}_{2}$ (Figure $\mathbf{1}$ ) display broad bands in the UV range centered at 232, 279 and 234, $303 \mathrm{~nm}$, respectively, due to $\pi \rightarrow \pi^{*}$ transitions. Upon formation of the $\mathrm{Tb}^{3+}$ or $\mathrm{Yb}^{3+}$ complexes, the lowenergy absorption bands undergo a bathochromic shift of 5-10 $\mathrm{nm}$. It is important to note a pronounced red-shift $(25 \mathrm{~nm}$, i.e. $320 v$ s. $345 \mathrm{~nm}$ ) of the cutoff wavelengths of the absorption bands upon conversion of $\mathbf{L n L}_{\mathbf{1}}$ to $\mathbf{L n L}_{2}$ which can be used to our advantage in the design of responsive probes.

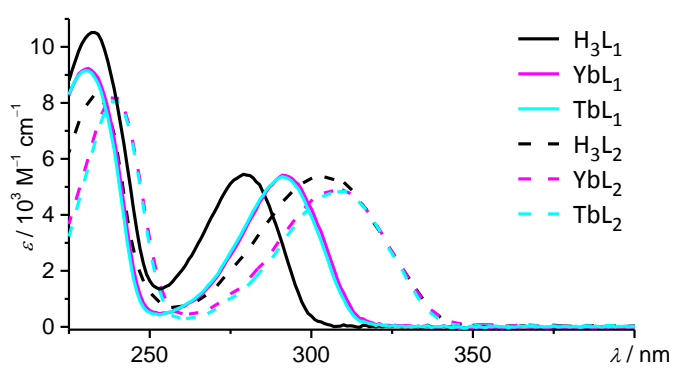

Figure 1. Absorption spectra of $\mathbf{H}_{3} \mathbf{L}_{\mathbf{1}}$ and $\mathbf{H}_{3} \mathbf{L}_{2}$ and their corresponding $\mathrm{Yb}^{3+}$ and $\mathrm{Tb}^{3+}$ complexes (100 $\mu \mathrm{M}$ in HEPES buffer, $\mathrm{pH}$ 7.4, room temperature).

Excitation spectra recorded upon monitoring of the main transitions of $\mathrm{Tb}^{3+}$ and $\mathrm{Yb}^{3+}$ ions at 545 and $980 \mathrm{~nm}$, respectively, match the shapes of the absorption ones, indicating that the sensitization of $\mathrm{Ln}^{3+}$ ions is occurring through the organic ligands (Figure 2, left). Upon excitation into ligand-centered absorption bands at 290$310 \mathrm{~nm}$, TbL and YbL complexes exhibit characteristic emission in the visible or the NIR range due to ${ }^{5} \mathrm{D}_{4} \rightarrow{ }^{7} \mathrm{~F}_{J}(J$ $=6-0$ ) or ${ }^{2} \mathrm{~F}_{5 / 2} \rightarrow{ }^{2} \mathrm{~F}_{7 / 2}$ transitions, respectively (Figure 2, center and right). The differences in Stark splitting of the $\mathrm{f}-\mathrm{f}$ transitions, that are more pronounced in the case of $\mathrm{Yb}^{3+}$ complexes, reflect changes in coordination environment around the $\mathrm{Ln}^{3+}$ ion.

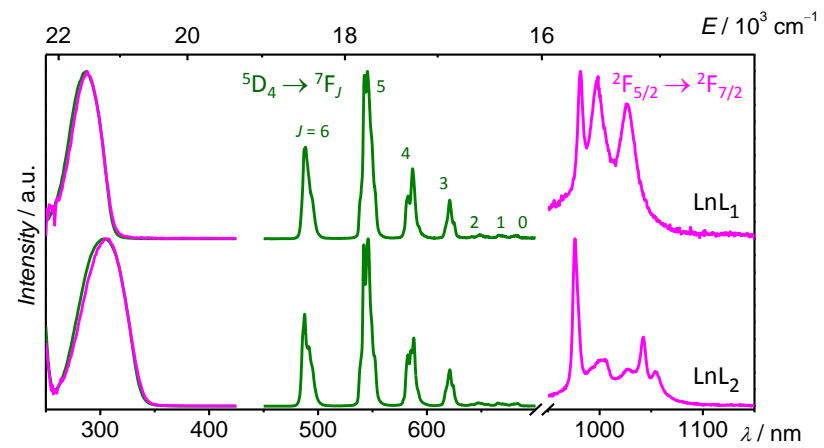

Figure 2. Left: excitation spectra of $\mathbf{L n L}_{\mathbf{1}}$ (top) and $\mathbf{L n} \mathbf{L}_{\mathbf{2}}$ (bottom) $\left(\lambda_{\mathrm{em}}=545 \mathrm{~nm}\left(\mathrm{~Tb}^{3+}\right)\right.$ and $\left.980 \mathrm{~nm}\left(\mathrm{Yb}^{3+}\right)\right)$; center and right: emission spectra of $\mathbf{L n L}_{\mathbf{1}}$ (top, $\lambda_{\mathrm{ex}}=290 \mathrm{~nm}$ ) and $\mathbf{L n L}_{\mathbf{2}}$ (bottom, $\lambda_{\mathrm{ex}}=310 \mathrm{~nm}$ ). $100 \mu \mathrm{M}$ in HEPES buffer, $\mathrm{pH} 7.4$, room temperature. $\mathrm{Ln}=\mathrm{Tb}^{3^{+}}$(green traces), $\mathrm{Yb}^{3+}$ (magenta traces).

Luminescence lifetimes and quantum yields have been determined in $\mathrm{H}_{2} \mathrm{O}$ and $\mathrm{D}_{2} \mathrm{O}$ solutions (Table $\mathrm{S}_{1}$ ). In $\mathrm{H}_{2} \mathrm{O}$, quantum yields and luminescence lifetime values of $\mathbf{T b L}_{1}$ are larger than those observed for $\mathbf{T b L}_{2}$ (37(1) vs. 22.2(2) $\%$ and 2.78(1) vs. 1.94(4) $\mathrm{ms}$ ) but are similar when placed in $\mathrm{D}_{2} \mathrm{O}(\sim 36 \%$ and $3 \mathrm{~ms})$, reflecting the role of $\mathrm{O}-\mathrm{H}$ vibrations in the latter complex. Indeed, comparison of $\tau_{\text {obs }}$ in $\mathrm{H}_{2} \mathrm{O}$ and $\mathrm{D}_{2} \mathrm{O}$ using phenomenological equations ${ }^{20}$ confirms that the $\mathrm{Tb}^{3+}$ ion is monohydrated in $\mathbf{T b} \mathbf{L}_{2}$ while no water molecule is coordinated to $\mathrm{Tb}^{3+}$ in $\mathbf{T b L}_{\mathbf{1}}$. For $\mathrm{Yb}^{3+}$ complexes, the situation is different due to the 
intrinsically higher impact of vibrations on the nonradiative quenching of luminescence. ${ }^{13,21}$ Quantum yield and lifetime values are lower even in $\mathrm{D}_{2} \mathrm{O}$ by 1.4-1.5 times for $\mathbf{Y b L}_{2}$ compared to $\mathbf{Y b L}_{1}(0.181(6)$ vs. $0.261(5) \%$ and 5.02(2) vs. $7.7(2) \mu s)$. This result can be explained by a stronger non-radiative quenching contribution of $\mathrm{N}-\mathrm{H}$ vibrations in $\mathbf{Y b L}_{2}$. Moreover, in $\mathrm{H}_{2} \mathrm{O}, \mathbf{Y b L}_{2}$ exhibits a biexponential luminescence decay with lifetimes of 1.44 and $0.77 \mu \mathrm{s}$. We can hypothesize the presence of an equilibrium between mono- and non-hydrated species in this case.

To analyze the abilities of the $\mathrm{Tb}^{3+}$ and $\mathrm{Yb}^{3+}$ complexes to operate as luminescence responsive probes upon elimination of the benzyl carbamate spacer, emission spectra of $\mathbf{L n L}_{\mathbf{1}}$ and $\mathbf{L} \mathbf{n} \mathbf{L}_{2}$ were measured under ligand excitation at $340 \mathrm{~nm}$ (Figure 3). The choice of the excitation wavelength was dictated by the differences in absorption for the two series of complexes (Figure 1). The integrated emission intensities of $\mathbf{T b L}_{2}$ and $\mathbf{Y b L}_{2}$ were found to be 20- and 6.5-times higher, respectively, than that of the corresponding $\mathbf{L n L}_{\mathbf{1}}$ complexes. Thus, conversion of visible $\left(\mathrm{Tb}^{3+}\right)$ or NIR $\left(\mathrm{Yb}^{3+}\right)$ emitting probes bearing the enzyme-specific substrate to $\mathbf{L n L}_{2}$ complexes will lead to a turn-on luminescence response which will be the first example of a NIR-emitting $\mathrm{Ln}^{3+}$ complex for monitoring enzymatic reactions.

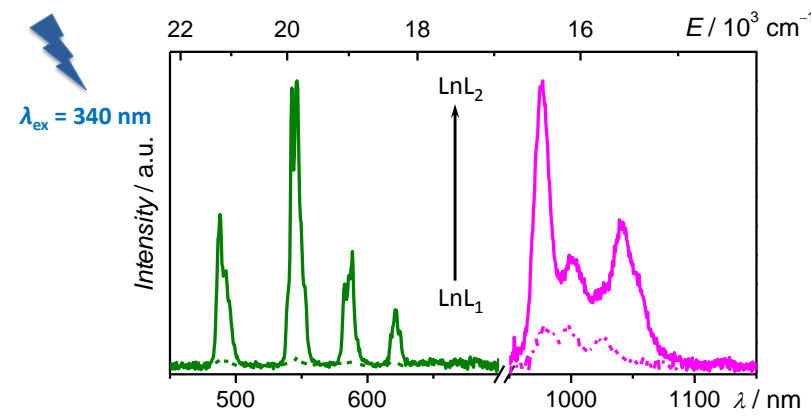

Figure 3. Demonstration of OFF-ON luminescence switch from $\mathbf{L n L}_{\mathbf{1}}$ (dotted line) to $\mathbf{L n L}_{\mathbf{2}}$ (plain line) under excitation at $340 \mathrm{~nm}$ (100 $\mu \mathrm{M}$ in HEPES buffer, $\mathrm{pH} 7.4$, room temperature). $\mathrm{Ln}=\mathrm{Tb}^{3+}$ (green traces), $\mathrm{Yb}^{3+}$ (magenta traces).

To assess the potentiality of the $\mathrm{Gd}^{3+}$ analogues as enzyme responsive $T_{1}$ MRI agents, longitudinal water proton relaxivities, $r_{1}$, were determined for $\mathbf{G d L}_{\mathbf{1}}$ and $\mathbf{G d L}_{2}$ (o-8o $\mathrm{MHz}, 25$ and $37^{\circ} \mathrm{C}$ ). At all fields and both temperatures, the $r_{1}$ values are considerably (90-100\%) larger for $\mathbf{G d L}_{2}$ than for $\mathbf{G d L}_{1}$ (Supporting Information; $r_{1}=1.91 \mathrm{mM}^{-1} \mathrm{~s}^{-1}$ and $3.77 \mathrm{mM}^{-1} \mathrm{~s}^{-1}$ for $\mathbf{G d L}_{1}$ and $\mathbf{G d L}_{2}$, respectively; $60 \mathrm{MHz}$, $25^{\circ} \mathrm{C}$ ). This relaxivity difference should lead to a remarkable turn-on response in $T_{1}$-MRI upon enzymatic activation of the probe. The low relaxivity of $\mathbf{G d L}_{\mathbf{1}}$ points to a non-hydrated state, in accordance with the crystal structure (Figure S8) and the luminescence lifetimes (see above), while the higher relaxivity of $\mathbf{G d L}_{2}$ is consistent with a monohydration of the $\mathrm{Ln}^{3+}$.

CEST spectra were recorded for $\mathbf{T b} \mathbf{L}_{1}, \mathbf{T b L}_{2}$ and $\mathbf{Y b \mathbf { L } _ { 1 }}$, $\mathbf{Y b L}_{2}$ complexes in aqueous solution by applying a 35 selective saturation at $25 \mu \mathrm{T}$ in $1 \mathrm{ppm}$ increments from -90 to $+90 \mathrm{ppm}\left(\mathrm{Yb}^{3+}\right)$ or -500 to $+400 \mathrm{ppm}\left(\mathrm{Tb}^{3+}\right)$ and plotted as normalized water signal intensity $\left(M_{z} / M_{o} \%\right)$ against frequency offset (ppm). A single CEST effect $(\sim 25 \%)$ was observed at $+44 \mathrm{ppm}$ for $\mathbf{Y b L}_{1}$, while two CEST peaks appear at -105 and -115 ppm for $\mathbf{T b L}_{\mathbf{1}}$ (Figure S2), which were assigned to carbamate protons. While amide protons are a common source of PARACEST in $\mathrm{Ln}^{3+}$ complexes, this is the first example of carbamate protons that generate PARACEST effect. In contrast, no CEST is produced by $\mathbf{L n L}_{2}$ analogues (Figures 4 and $\mathbf{S}_{2}$ ). Thus, the conversion of the carbamate complexes to the amine analogues upon enzymatic reaction will lead to a turn-off PARACEST response. For $\mathbf{T b L}_{\mathbf{1}}$, the two CEST peaks likely belong to two isomers, as it was reported for $\mathrm{YbHPDO}_{3} \mathrm{~A}^{22}$ Indeed, $\mathrm{Ln}^{3+}$ complexes of cyclen-based ligands may exist as two diastereomeric pairs, ${ }^{23}$ which are observable in the ${ }^{1} \mathrm{H}$ NMR spectrum of $\mathbf{T b L}_{\mathbf{1}}$ (Figure $\mathrm{S}_{23}$ ). The two CEST signals belonging to the same molecule can be later exploited for a ratiometric calibration that reports on enzyme activities irrespective of probe concentration.

The exchange rate of the mobile carbamate protons has been assessed by QUEST measurements for $\mathbf{Y b L}_{1}$ $\left(k_{\mathrm{ex}}=6100 \pm 100 \mathrm{~s}^{-1}\right)$ and by the omega plot method for the two isomers of $\mathbf{T b L}_{1}\left(k_{\mathrm{ex}}=4300 \pm 300 \mathrm{~s}^{-1}\right.$ at $-115 \mathrm{ppm}$ and $5000 \pm 400 \mathrm{~s}^{-1}$ at $\left.-105 \mathrm{ppm} ; \mathrm{pH} 7 \cdot 4,25^{\circ} \mathrm{C}\right)$. They are similar or slightly higher compared to values reported for $\mathrm{Ln}^{3+}$ tetraamide DOTA-derivatives with PARACEST effect. ${ }^{24}$

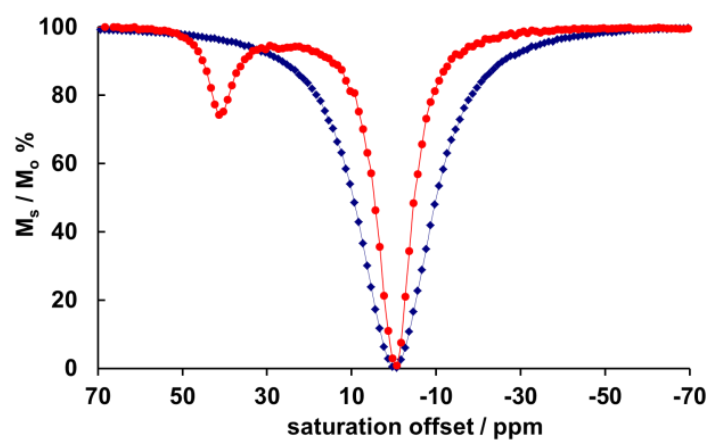

Figure 4. CEST spectra of $\mathbf{Y b L}_{1}$ (red) and $\mathbf{Y b L}_{2}$ (blue). 500 $\mathrm{MHz}, \mathrm{pH} 7.5,37^{\circ} \mathrm{C}$, irradiation power $25 \mu \mathrm{T}$, saturation time $3 \mathrm{~s},[\mathrm{YbLi}]_{\mathrm{i}=1,2}=20 \mathrm{mM}$.

To further demonstrate the utility of our platform system, we have acquired $T_{1}$-weighted and CEST MR images of the $\mathrm{Gd}^{3+}$ and $\mathrm{Yb}^{3+}$ complexes, respectively (Figure 5). These images are in accordance with the relaxivities of $\mathbf{G d L}_{1}$ and $\mathbf{G d L}_{2}$ and with the CEST effect observed for $\mathbf{Y b L}_{1}$. They evidence the potential of obtaining MRI detectable responses upon the transformation of the carbamate to the corresponding amine derivative complexes, representing off/on or on/off responses in $T_{1}$ or CEST MRI, respectively.

In conclusion, we have designed, synthesized and characterized the physico-chemical properties of complexes formed with a ligand system that can be tuned for specific detection of a wide variety of enzymatic activities using complementary detection modalities including visible and NIR optical imaging, $T_{1}$ or PARACEST MRI depending on the nature of the $\mathrm{Ln}^{3+}$ ion. A common triggering molecular mechanism is used for 
the operation of different imaging modalities. $\mathbf{L n L}_{\mathbf{1}}$ and $\mathbf{L n L}_{2}$ complexes described here model the states priorand post-enzymatic cleavage occurring in these probes.
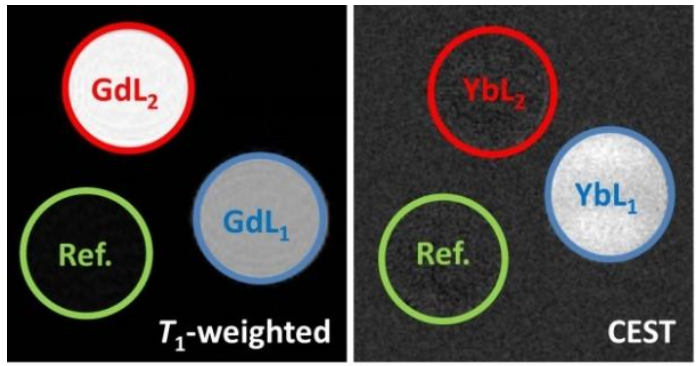

Figure 5. $T_{1}$ weighted and CEST MR images of phantoms containing complexes of $\mathbf{H}_{3} \mathbf{L}_{\mathbf{1}}$ and $\mathbf{H}_{3} \mathbf{L}_{2}$ with $\mathrm{Gd}^{3+}(2.86 \mathrm{mM}$, $\mathrm{pH}$ 7.8) and $\mathrm{Yb}^{3+}$ (20.8 mM; $\mathrm{pH}$ 7.0). $T_{1}$ weighted images were acquired at $7 \mathrm{~T}$ using spin echo sequence with $\mathrm{TE}=11.0 \mathrm{~ms}$ and $\mathrm{TR}=$ 20oms. CEST difference images were obtained by subtracting on-resonance (+44 ppm) from off-resonance (-44 ppm) images at 9.4 $\mathrm{T}$ (irradiating pulse of $25 \mu \mathrm{T}, 4 \mathrm{~s}$ ).

This is the first example where a single molecular system can be used as a responsive imaging agent in three different independent modalities. In these compounds, we have evidenced a remarkable variation in relaxivity $\left(\mathrm{Gd}^{3+}\right)$, in PARACEST as well as in luminescence properties $\left(\mathrm{Tb}^{3+}\right.$ and $\left.\mathrm{Yb}^{3+}\right)$ which open the way towards multimodal enzyme detection by using a single ligand.

\section{ASSOCIATED CONTENT}

Supporting Information. Synthetic procedures, compound characterization, ${ }^{1} \mathrm{H}$ NMR, NMRD, CEST spectra, photophysical measurements, ORTEP plot, crystallographic information, CIF files, HPLC analyses. This material is available free of charge via the Internet at http://pubs.acs.org.

\section{AUTHOR INFORMATION}

\section{Corresponding Authors}

* philippe.durand@cnrs.fr; eva.jakabtoth@cnrs.fr; stephane.petoud@inserm.fr

\section{Author Contributions}

The manuscript was written through contributions of all authors. All authors have given approval to the final version of the manuscript.

\section{ACKNOWLEDGMENT}

This research was supported by ANR (ENZYMAGE), La Ligue Contre le Cancer and carried out within European COST actions TDioo4 and CM1oo6, and Cancéropôle Grand Ouest. S.P. acknowledges support from INSERM and J.H. acknowledges the French research ministry for her grant.

\section{REFERENCES}

(1) (a) Jung, K.-H.; Lee, K.-H. J. Pathol. Transl. Med. 2015, 49, 5 (b) Hussain, T.; Nguyen, Q. T. Adv. Drug Deliver. Rev. 2014, 66, 9o. (c) Molecular imaging: principles and practice; Weissleder, R.; Ross, B. D.; Rehemtulla, A.; Gambhir, S. S., Eds.; People's Medical Publishing House: Shelton, 2010.

(2) The Chemistry of Molecular Imaging; Long, N. J.; Wong, W.-T., Eds.; Wiley: New York, 2015.
(3) (a) Hingorani, D. V.; Bernstein, A. S.; Pagel, M. D. Contrast Media Mol. Imaging 2015, 10, 245. (b) Boros, E.; Gale, E. M.; Caravan, P. Dalton Trans. 2015, 44, 4804. (c) Bonnet, C. S.; Tei, L.; Botta, M.; Toth, E. In Chemistry of Contrast Agents in Medical Magnetic Resonance Imaging (2nd Edition); Merbach A., Helm L., Tóth É., Eds.; John Wiley \& Sons Ltd.: 343, 2013 . (d) Terreno, E.; Castelli, D. D.; Aime, S. In Chemistry of Contrast Agents in Medical Magnetic Resonance Imaging (2nd Edition); Merbach A., Helm L., Tóth É., Eds.; John Wiley \& Sons Ltd.: 387, 2013.

(4) (a) Lou, Z.; Li, P.; Han, K. Acc. Chem. Res. 2015, 48, 1358. (b) Kobayashi, H.; Choyke, P. L. Acc. Chem. Res. 2o11, 44, 83.

(5) van Rooij, T.; Daeichin, V.; Skachkov, I.; de Jong, N.; Kooiman, K. Int. J. Hyperthermia 2015, 31, 90.

(6) Van de Bittner, G. C.; Ricq, E. L.; Hooker, J. M. Acc. Chem. Res. 2014, 47, 3127.

(7) (a) Seibold, U.; Wängler, B.; Schirrmacher, R.; Wängler, C. Biom. Res. Int. 2014, 2014, 13. (b) Chiang, S. Frontiers in Neurology 2015, 6, 74. (c) Kobayashi, H.; Longmire, M. R.; Ogawa, M.; Choyke, P. L. Chem. Soc. Rev. 2011, 40, 4626.

(8) (a) Srivastava, A. K.; Kadayakkara, D. K.; Bar-Shir, A.; Gilad, A. A.; McMahon, M. T.; Bulte, J. W. M. Dis. Model. Mech. 2015, 8, 323. (b) Hingorani, D. V.; Yoo; Bernstein, B., A. S.; Pagel,. M. D. Chem. Eur. J. 2014, 20, 9840. (c) Razgulin, A.; Ma, N.; Rao, J. Chem. Soc. Rev., 2011, 40, 4186.

(9) (a) Reilly, R. M.; Lam, K.; Chan, C.; Levine, M. Bioconjugate Chem. 2015, 26, 625. (b) Pierre, V.; Allen, M.; Caravan, P. J. Biol. Inorg. Chem. 2014, 19, 127. (c) Heffern, M. C.; Matosziuk, L. M.; Meade, T. J. Chem. Rev. 2014, 114, 4496. (d) Wolfbeis, O. S. Angew. Chem. Int. Edit. 2013, 52, 9864.

(10) (a) Chen, K.; Chen, X. Y. Curr. Top. Med. Chem. 2o10, 10, 1227. (b) Pershagen, E.; Borbas, K. E. Angew. Chem. Int. Ed. 2015, 54,1787 .

(11) Chauvin, T.; Durand, P.; Bernier, M.; Meudal, H.; Doan, B. T.; Noury, F.; Badet, B.; Beloeil, J. C.; Toth, E. Angew. Chem. Int. Edit. 20o8, 47, 4370.

(12) Smith, A. M.; Mancini, M. C.; Nie, S. Nat. Nanotechnol. 2009, 4, 710 .

(13) Comby, S.; Bünzli, J.-C. G. In Handbook on the Physics and Chemistry of Rare Earths. Gschneidner Jr., K. A., Bünzli, J.-C. G., Pecharsky, V. K., Eds.; Elsevier Science B.V.: Amsterdam, 2007; Vol. 37, Ch. 235, p 217.

(14) (a) Foucault-Collet, A.; Shade, C. M.; Nazarenko, I.; Petoud, S.; Eliseeva, S. V. Angew. Chem. Int. Edit. 2014, 53, 2927. (b) Foucault-Collet, A.; Gogick, K. A.; White, K. A.; Villette, S.; Pallier, A.; Collet, G.; Kieda, C.; Li, T.; Geib, S. J.; Rosi, N. L.; Petoud, S. P Natl. Acad. Sci. USA 2013, 110, 17199.

(15) (a) Bünzli, J.-C. G.; Eliseeva, S. V. In Comprehensive Inorganic Chemistry II; Yam, V. W.-W., Ed.; Elsevier B.V.: Amsterdam, 2013; Vol. 8, p 339. (b) Trivedi, E. R.; Eliseeva, S. V.; Jankolovits, J.; Olmstead, M. M.; Petoud, S.; Pecoraro, V. L. J. Am. Chem. Soc. 2014, 136, 1526.

(16) Amoroso, A. J.; Pope, S. J. A. Chem. Soc. Rev. 2015, 44, 4723.

(17) Hancock, R. D. Chem. Soc. Rev. 2013, 42, 1500.

(18) (a) de Bettencourt-Dias, A.; Barber, P. S.; Viswanathan, S. Coord. Chem. Rev. 2014, 273-274, 165. (b) Uh, H.; Petoud, S. Comptes Rendus Chimie, 2010, 13, 668.

(19) Alouane, A.; Labruère, R.; Le Saux, T.; Schmidt, F.; Jullien, L. Angew. Chem. Int. Edit. 2015, 54, 7492.

(20) Beeby, A.; Clarkson, I. M.; Dickins, R. S.; Faulkner, S.; Parker, D.; Royle, L.; de Sousa, A. S.; Williams, J. A. G.; Woods, M. J.Chem.Soc., Perkin Trans.2 1999, 493.

(21) Bünzli, J.-C. G.; Eliseeva, S. V. J. Rare Earth. 2010, 28, 824.

(22) Delli Castelli, D.; Terreno, E.; Aime, S. Angew. Chem. Int. Edit. 2011, 50, 1798.

(23) Platas-Iglesias, C. Eur. J. Inorg. Chem. 2012, 2012, 2023.

(24) Zhang, S. R.; Michaudet, L.; Burgess, S.; Sherry, A. D. Angew. Chem. Int. Edit. 2002, 41, 1919. 
For Table of Contents Only

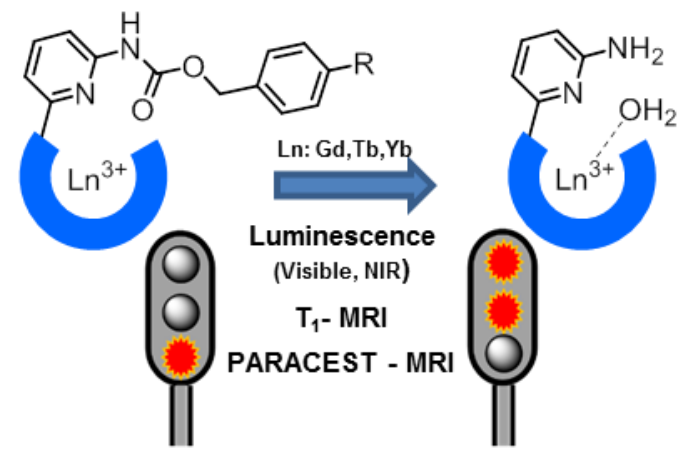

